\title{
Novel aspects of exercise training to promote human metabolic health
}

Citation for published version (APA):

Mancilla Fuentes, R. F. (2022). Novel aspects of exercise training to promote human metabolic health. [Doctoral Thesis, Maastricht University]. Proefschriftmaken.nl || Uitgeverij BOXPress.

https://doi.org/10.26481/dis.20220210rm

Document status and date:

Published: 01/01/2022

DOI:

10.26481/dis.20220210rm

Document Version:

Publisher's PDF, also known as Version of record

\section{Please check the document version of this publication:}

- A submitted manuscript is the version of the article upon submission and before peer-review. There can be important differences between the submitted version and the official published version of record.

People interested in the research are advised to contact the author for the final version of the publication, or visit the DOI to the publisher's website.

- The final author version and the galley proof are versions of the publication after peer review.

- The final published version features the final layout of the paper including the volume, issue and page numbers.

Link to publication

\footnotetext{
General rights rights.

- You may freely distribute the URL identifying the publication in the public portal. please follow below link for the End User Agreement:

www.umlib.nl/taverne-license

Take down policy

If you believe that this document breaches copyright please contact us at:

repository@maastrichtuniversity.nl

providing details and we will investigate your claim.
}

Copyright and moral rights for the publications made accessible in the public portal are retained by the authors and/or other copyright owners and it is a condition of accessing publications that users recognise and abide by the legal requirements associated with these

- Users may download and print one copy of any publication from the public portal for the purpose of private study or research.

- You may not further distribute the material or use it for any profit-making activity or commercial gain

If the publication is distributed under the terms of Article $25 \mathrm{fa}$ of the Dutch Copyright Act, indicated by the "Taverne" license above, 


\section{CHAPTER 8}

Summary 


\section{Summary}

The prevalence of obesity has increased exponentially worldwide (1). Obesity is a crucial contributing factor to the development of cardiovascular disorders, type 2 diabetes mellitus (T2DM) and non-alcoholic fatty liver disease (2). In fact, obese/overweight individuals are characterized by an impaired whole-body insulin sensitivity (3) and reduced skeletal muscle mitochondrial function (4), which in turn negatively affect plasma glucose homeostasis.

Regular exercise training is a well-recognized lifestyle intervention to prevent and counteract obesity-related metabolic disorders. Classically, exercise volume and intensity are regarded as the main factors determining the benefits of exercise in metabolic health. Hence, exercise volume and intensity provide the physiological rationale of the conventional recommendations of performing at least 150 minutes of moderate intensity aerobic-type combined with resistanttype exercise per week (5). However, the effects of these conventional exercise recommendations differ in magnitude among individuals, showing the need to come up with novel strategies to optimize the effects of exercise.

Many physiological processes in the human body, such as hormone synthesis and glucose homeostasis, exhibit day-night cycles, orchestrated by the central molecular clock which is located in the suprachiasmatic nucleus of the hypothalamus (6). Interestingly, peripheral organs such as liver, adipose tissue and skeletal muscle, contain their own molecular clocks (6). Of note, experimentally induced circadian misalignment causes skeletal muscle insulin resistance in normoglycemic individuals (7), which can be mitigated by performing acute bouts of high intensity interval exercise (8). Such insights that the biological clock, glucose homeostasis and exercise metabolism are tightly intertwined substantiate the hypothesis that the timing of exercise can be used to optimize its insulin sensitizing and metabolic benefits. The link between the skeletal muscle molecular clock and the benefits of exercise on glucose metabolism are reviewed in chapter 2. In this chapter, it is discussed how the nutritional status pre-post exercise, as well as the tissue-specific energy depots might influence the effects of exercise timing on glucose metabolism, with special emphasis on insulin resistant and type 2 diabetic individuals. This hypothesis was subsequently tested in chapter $\mathbf{3}$, in which state-of-the-art methodologies are used to investigate the effects of exercise timing on skeletal muscle insulin sensitivity and other clinical parameters in metabolically compromised individuals. We showed that afternoon exercise training confers superior benefits as compared to morning 
exercise training in skeletal muscle insulin sensitivity, body composition and exercise performance in obese, metabolically compromised individuals.

Of note, obesity-related metabolic disorders and sedentary aging are often accompanied by exercise intolerance (9), likely explained by a refractory myocellular ATP synthesis via mitochondrial metabolism at the onset of exercise. The delayed responsiveness of skeletal muscle mitochondrial ATP synthesis is known as mitochondrial inertia (10). The responsiveness of skeletal muscle mitochondrial ATP synthesis at the onset of exercise relies on the intramyocellular acetyl-coa availability (10), which is controlled by the mitochondrial enzyme carnitine acetyltransferase (CrAT) (11). In chapter 4, the responsiveness of skeletal muscle mitochondrial ATP production at the onset of exercise, its potential underlying mechanisms, and its association with functional read-outs of exercise intolerance were determined in two different cohorts of human volunteers. The responsiveness of skeletal muscle ATP synthesis at the onset of exercise was slower in older, metabolically compromised individuals as compared to young, endurance-trained volunteers as well as in elderly, normally physically active individuals as compared to young, healthy and elderly exercise-trained counterparts. The responsiveness of skeletal muscle ATP synthesis at the onset of exercise was tightly linked to functional outcomes, which coexisted with reduced CrAT activity, low acetylcarnitine levels and elevated ADP concentration in muscle tissue during exercise. These results indicate that mitochondrial inertia at the onset of exercise might emerge as a target for intervention to improve exercise tolerance.

Given the wide variety of methods to assess skeletal muscle mitochondrial function, a direct comparisons and validation of the different markers of mitochondrial function with gold standard measures are needed. In chapter $\mathbf{5}$ we determined to what extent different in vitro markers of mitochondrial content and in vivo functional readouts for skeletal muscle and whole-body oxidative capacity reflect muscle mitochondrial respiratory capacity as determined ex vivo, by high resolution respirometry.

Of the in vitro markers, protein content for complex $\mathrm{V}$ of the oxidative phosphorylation system and citrate synthase (CS) activity are the most valid surrogate markers of skeletal muscle mitochondrial respiratory capacity. From the in vivo readouts for skeletal muscle and wholebody oxidative capacity, $\mathrm{PCr}$ recovery post exercise, maximal aerobic capacity and exercise efficiency are valid reflection of skeletal muscle mitochondrial respiratory capacity. These results are of relevance for researchers to make a good choice from the multitude of techniques 
that are available, when determining mitochondrial function. In addition, these findings might benefit researchers aiming to investigate skeletal muscle mitochondrial function but do not posse the gold standard technique to do so, and for studies that may not be able to incorporate muscle biopsies.

Most adults with poor metabolic health fail to meet the recommendations of performing at least 150 minutes of physical activity per week, with a "lack of time" being the most commonly cited barrier (12). In this regard, there has been a flourishing appreciation for the capability of high intensity interval training (HIIT) to improve metabolic health, as this methodology needs at least $50 \%$ less time commitment as compared to exercise performed according to the conventional exercise recommendations (13). In chapter 6, we investigated if 12 weeks of HIIT prompts beneficial effects on insulin sensitivity, muscle mitochondrial capacity and intrahepatic lipid (IHL) content in obese adults. Given the frequent consumption of carbohydrate rich and insulinogenic sports drinks after a training session, we also explored if co-ingestion of a standardized glucose and casein hydrolysate post-exercise affects the HIITmediated metabolic improvements. HIIT enhanced insulin sensitivity, skeletal muscle mitochondrial capacity, decreased intrahepatic lipid content and modified intrahepatic lipid composition in obese adults. These benefits were attained regardless of co-ingesting glucose and proteins after exercise and in the absence of changes in body weight and body composition. Taken together, HIIT is an effective training method to enhance metabolic health in obese adults.

Overall, the results from this thesis provide novel information about exercise timing as contributing factor to optimize the benefits of exercise in metabolic health. Also, the results of this thesis demonstrate that high intensity interval training is an effective training modality to improve whole-body insulin sensitivity, skeletal muscle mitochondrial capacity and to decrease and modify liver fat content and composition in obese adults. In addition, the results of this thesis indicate that skeletal muscle mitochondrial inertia is a novel signature of skeletal muscle mitochondrial function that correlates with markers for daily life activity. Thus, mitochondrial inertia is a putative target of intervention to improve physical function in metabolically compromised and elderly individuals. Furthermore, this thesis shows which markers of mitochondrial content and functional readouts of muscle oxidative capacity reflect muscle mitochondrial respiratory capacity ex vivo. Thus, the results of this thesis provide valuable 
additions to the current literature about how to exploit the benefits of regular exercise training in human metabolic health. 


\section{References}

1. Afshin A, Forouzanfar MH, Reitsma MB, Sur P, Estep K, Lee A, et al. Health Effects of Overweight and Obesity in 195 Countries over 25 Years. N Engl J Med. 2017;377(1):13-27. 2. Kopelman P. Health risks associated with overweight and obesity. Obes Rev. 2007;8 Suppl 1:13-7.

3. Shulman GI. Ectopic fat in insulin resistance, dyslipidemia, and cardiometabolic disease. N Engl J Med. 2014;371(12):1131-41.

4. Schrauwen-Hinderling VB, Kooi ME, Hesselink MK, Jeneson JA, Backes WH, van Echteld CJ, et al. Impaired in vivo mitochondrial function but similar intramyocellular lipid content in patients with type 2 diabetes mellitus and BMI-matched control subjects. Diabetologia. 2007;50(1):113-20.

5. Colberg SR, Sigal RJ, Fernhall B, Regensteiner JG, Blissmer BJ, Rubin RR, et al. Exercise and type 2 diabetes: the American College of Sports Medicine and the American Diabetes Association: joint position statement. Diabetes Care. 2010;33(12):e147-67.

6. Mohawk JA, Green CB, Takahashi JS. Central and peripheral circadian clocks in mammals. Annu Rev Neurosci. 2012;35:445-62.

7. Wefers J, van Moorsel D, Hansen J, Connell NJ, Havekes B, Hoeks J, et al. Circadian misalignment induces fatty acid metabolism gene profiles and compromises insulin sensitivity in human skeletal muscle. Proc Natl Acad Sci U S A. 2018;115(30):7789-94.

8. Saner NJ, Lee MJ, Kuang J, Pitchford NW, Roach GD, Garnham A, et al. Exercise mitigates sleep-loss-induced changes in glucose tolerance, mitochondrial function, sarcoplasmic protein synthesis, and diurnal rhythms. Mol Metab. 2021;43:101110.

9. Ryan A, Wallace E, O'Hara P, Smith SM. Multimorbidity and functional decline in community-dwelling adults: a systematic review. Health Qual Life Outcomes. 2015;13:168.

10. Greenhaff PL, Campbell-O'Sullivan SP, Constantin-Teodosiu D, Poucher SM, Roberts PA, Timmons JA. An acetyl group deficit limits mitochondrial ATP production at the onset of exercise. Biochem Soc Trans. 2002;30(2):275-80.

11. Seiler SE, Koves TR, Gooding JR, Wong KE, Stevens RD, Ilkayeva OR, et al. Carnitine Acetyltransferase Mitigates Metabolic Inertia and Muscle Fatigue during Exercise. Cell Metab. 2015;22(1):65-76.

12. Trost SG, Owen N, Bauman AE, Sallis JF, Brown W. Correlates of adults' participation in physical activity: review and update. Med Sci Sports Exerc. 2002;34(12):1996-2001.

13. Hawley JA, Gibala MJ. What's new since Hippocrates? Preventing type 2 diabetes by physical exercise and diet. Diabetologia. 2012;55(3):535-9. 